\title{
An Analysis of the Use of Money to Divert the Exercise of Government Power for the Wealthiest
}

\section{Austin Murphy*}

\begin{abstract}
This paper utilizes a simple mathematical model of the relationship between wealth and political power to indicate the extent to which the wealthiest agents can control government leaders through their investments in politicians and parties that enable them to maximize their return on this political capital just as they do with any commercial investments. This power over government policies is shown to sometimes be efficiently facilitated at the
\end{abstract}

lowest cost through focusing voter choices on divisive issues. The control of government by private elites is demonstrated to be largely unhindered by any feasible limitations on political spending.

Keywords: lobbying, political capital, elections, money, government, Marxism

JEL Code: D72

Athough the contradictions of capitalist Apolitical economies were hypothesized by Marx (1848) to lead to an inevitable leftward revolt by the less affluent against unrestrained free market processes, ${ }^{1}$ the recent financial

\footnotetext{
*Professor of Finance, Oakland University

${ }^{1}$ The contradictions involve the value of labor in surplus of its cost of reproduction being exploited by a capitalist elite to whom workers are economically enslaved for their existence, which itself is driven by the cyclical forces of capitalism into desperate extremes during the inevitable economic downturns. Economic cycles in capitalism stem from the motivation owners of saved money have to make productivity investments in order to increase the efficiency of production and thereby maximize the return on their invested savings (Marx, 1867, 1885, 1894). The large profits from these capital expenditures in technology and economies of scale by some businesses eventually cause losses to competing firms that do not to match the investments of the most efficient companies. Competitive forces then cause increasing production that eventually drives profits or surplus labor value down to a point where further investment no longer earns a sufficiently high real return to motivate further capital expenditures. With falling investment of saved surplus value, the supply of goods and services exceeds the monetary demand from the sum of wages paid to labor and any profits which capitalists want to consume out of their surplus value of labor of others they have saved for themselves. The surplus supply then causes businesses to reduce production that leads to decreased employment of workers that further reduces demand from wages and thereby exasperates the excess supply of goods and services in a self-reinforcing cycle. The economic recession continues until the oversupply of past overproduced goods and productive capacity are absorbed, where prices are low enough to clear production at the falling demand, so that production and investment become profitable again. The cycle of overproduction followed by a bust then resumes. The downward economic swings in capitalism create misery among the workers that motivates them to revolt against the capitalists, upon which whom they are dependent for their livelihood. Strikes and riots may occur that reduce capitalist profits, as well as movements to replace the capitalist systems of political economy, and, despite the extensive efforts by the capitalist elites to suppress revolts, rebellions have occasionally occurred in some countries that resulted in the overthrow of the existing systems (Murphy, 2000). To inhibit such events harmful to the capitalists' interests, governments typically offer some current benefits to the poorer members of society to reduce their present feelings of aggrievement below a dangerous level, with the costs of those benefits financed with debt, which, however, reduces the ability of the government to continue those benefits in the future and tends to thereby create resignation among the aggrieved that reduces their revolutionary fervor (Passarelli and Tabellini,
} 


\section{Articles}

and economic crisis of 2007-2009 has led to a worldwide political trend toward authoritarian free markets under right-wing governments that increase the wealth of the richest members of society. The latter extreme downturn in the value of financial assets and economic production was initially spurred by financial institutions being motivated to create excessive debt securities at yields that did not compensate for risk and that could not be paid back (Kolb, 2010). A bubble in artificial demand for financial assets resulted that spilled over into the overpricing of real estate and that was followed by a bust in the markets for both financial and real assets. ${ }^{2}$ The resulting worldwide economic recession and stock market crash were only reversed via extraordinarily expansive monetary and fiscal policies of governments. ${ }^{3}$

The recent financial crisis and trend toward more extreme concentrations of wealth in the subsequent economic rebound has driven the working classes in the direction of revolution (Holmes, 2018). However, despite an increasing share of national income having gone into business profits in recent years that naturally lead to widespread "populist" reactions (Economist, 2018v), the most powerful political movements have largely diverted people's energy into social divisions relating to ethnicity, religion, sex, and nationhood while strengthening the existing structure of capitalist economic relations in which market forces enable the exploitation of labor by capital (Catalinotto, 2018). The election of a fascist-style politician in Brazil in late October 2018 provides the most recent example of right-wing politicians using divisive special interests and scapegoating of various people to divert revolutionary energy away from the dynamic processes of capitalist political economies that serve the owners of capital (Raposo, 2019).

The exact processes by which rich elites can direct political movements and control government representatives subject to election by the people merit clarification via precise economic analysis. This paper utilizes a simple mathematical model of the interaction between any political system and the corporate drive for more profits to show why governments under capitalism inevitably

2017). The debt overhang itself is then publicly perceived by the elite decision-makers to represent an opportunity to cut taxes and reduce government spending (Kaske, 2019).

${ }^{2}$ Borrowing including through financial intermediaries like banks, can temporarily increase consumption and delay economic busts (Keynes, 1936). However, such spending merely prolongs over-investment and exasperates downturns in production that eventually occur when debtors are unable to afford to continue increasing consumption beyond their means, thereby resulting in an inability of the indebted to pay back their creditors and thus leading to financial crises and more extreme economic busts, as the increased debt merely exasperates the supply-and-demand imbalances intrinsic to capitalism (Marx, 1867, 1885, 1894).

${ }^{3}$ To help provide macroeconomic balance in supply and demand, governments can assist through running fiscal budget deficits, where government spending exceeds tax revenue, thereby usurping surplus saving into public spending through government borrowings according to the classical capitalist theories of economic behavior (Keynes, 1936). Government expenditures can be applied to investment in human capital, infrastructure development, and public projects as well as for social consumption and transfers that alleviate poverty and hence inhibit the economic desperation which motivates revolts. However, the amount of real government deficit spending is restricted to how much in future taxation can be willingly assumed by the wealthy, and so fiscal deficits merely postpone or exasperate the inevitable economic downturns. Systems with artificial mediums of exchange (i.e., intrinsically worthless coins and paper not backed by any real goods) that is created by the government which deems it to be legal tender for transactions supply additional means to extend booms. For instance, this currency issued and created by the government or central bank without real costs can be utilized to purchase excess debt of the government and others. Nevertheless, inflation inevitably results when the artificial monetary supply exceeds the demand of those with the money. As the monetary prices of production rise to bring the supply and demand of created money into equilibrium, the problem of real demand still being less than the real supply of goods and services reappears and can only be resolved by further increases in the supply of paper money that creates more inflation. This process, if continued, inevitably drives the transaction value of the paper down to its worthless value without resolving long-term the imbalance between the real supply and demand for production. 


\section{Articles}

serve to maximize the wealth of the elites. Being based on well-accepted economic theory, it provides a mathematical explanation for the control of government power by the wealthy at minimal costs, including via strategies that efficiently divert voter choices into political issues unrelated to the economic interests of the elites. Limitations on political spending are shown to be impotent in avoiding this outcome.

Relevant research on money controlling government policy is provided in Section I. In Section II, a formal mathematical model of politics is used to precisely explains the economic parameters involved that enable money to buy politicians and the government power it molds. Section III indicates how non-economic issues are exploited by the economic elites to divide and divert political attention. Section IV indicates why existing limitations on political spending do not hinder control of government power by the wealthy, and Section V summarizes the insights developed in this paper. Appendix I provides numerous recent examples from the recent press illustrating the many different methods employed by the rich and their controlled companies to buy government power across the world, while Appendix II precisely indicates the seemingly insurmountable obstacles faced by challenges to that control.

\section{Introduction}

Empirical research has documented the ability of the wealthy to engage in political spending which influences politicians and hence government actions. Stigler (1971) long ago explained the profit motivation that corporations have to exert influence over government through their costly political lobbying activities. Special interests with economic wealth have been shown to make election campaign contributions to politicians that impact government policies which affect
An Analysis of the Use of Money to Divert the Exercise of Government Power for the Wealthiest

those interests even if they are unpopular with informed voters (Bassetti and Pavesi, 2017). Public opinion can also be molded through donations to non-profit organizations that serve their donors (Wang and Qian, 2012). Even very strongly entrenched views on issues can be changed over time through effective political marketing (Green, McGrath, and Aronow, 2013). Although public knowledge of large political expenditures for any candidate can negatively impact the popularity of that politician, a large amount of political spending is legally undisclosed (Dowling and Wichowsky, 2013).

Many studies in the recent academic literature indicate that corporations earn huge returns on their expenditures to influence government decision making. For instance, large gains in shareholder value have been found to be derived by the political expenditures of corporations, as demonstrated by Ansolabehere, de Fiueiredo, and Snyder (2003), Cooper, Gulen, and Ovtchinnovkov (2010), and Hill, Kelly, Lockhart, and Van Ness (2013). High returns to stocks from the election of politicians relatively favorable to firms' operations have been found to continue over long periods of time (Addoum, Delikouras, Ke, and Kumar (2018). However, such researchers were perplexed as to the mechanics of that control enabling such high returns on expended political capital that don't seem to be consistent with capitalist theories of marginal revenues equaling marginal costs.

The impact of special interests in affecting politicians and their actions in government offices has long been integrated into the most modern theories of the economic and political sciences (Baron, 1994). The political spending of special interest groups has been shown empirically as well as politically to be instrumental in determining the outcomes of elections to government offices that serve the donors (Bombardini and Trebbi, 2011). 


\section{Articles}

However, those theories are typically based on assumptions of special interest money only affecting the choices of uninformed voters (Bassetti and Pavesi, 2017) and generally ignore the persuasive power of political marketing expenditures in impacting the ballot selections of eligible voters with contrary views. Implied in those previous models of capitalist democracies is an assumption that eligible voters cast ballots for representatives serving their own interests (Grossman and Helpman, 1996), thus ignoring the impact of manipulative political marketing, which Huber and Arceneaux (2007) as well as others have found to affect voter choices.

\section{A General Model of Money Buying of Government Power}

Modern theories of political economy generally assume that all people act to maximize their happiness which is mathematically defined by a Von NeumannMorgenstern (1953) utility function. ${ }^{4}$ Each person and organization representing special interests will therefore maximize the value of

$$
\mathrm{b}_{\mathrm{j}: \mathrm{n}}-\mathrm{c}_{\mathrm{j}: \mathrm{n}}>0 \text {, }
$$

where $b(c)$ is the benefit (cost) to the first subscripted agent from any political action, with the second subscripted agent after the colon denoting the source of the benefit (recipient of the cost paid), $\mathrm{n}$ specifies a politician, and $\mathrm{j}$ indicates other agents. In particular, $b_{i: n}$ represents a monetary value that measures the gross utility derived by any eligible political participant(s) j arising from an expenditure of $c_{i: n}$, which indicates the amount of expenditures $\mathrm{j}$ decides to make to influence any politician $\mathrm{n}$.

Because $c_{\text {:n }}$ represents the monetary benefit to politician $n$ from j's expenditure, all $\mathrm{n}$ will seek to maximize

$$
\mathrm{b}_{\mathrm{n}}=\mathrm{c}_{\mathrm{j}: \mathrm{n}}+\mathrm{b}_{\mathrm{n}: \mathrm{j}^{*}}
$$

where $\mathrm{b}^{*}{ }_{\mathrm{n}: \mathrm{j}}$ is the positive, negative, or zero expected value to $\mathrm{n}$ of accepting a political contribution from $j$ that may include at least n's tacit commitment to serve $\mathrm{j}$ through pushing the government policies desired by $\mathrm{j}$ if $\mathrm{n}$ is elected. Politicians are motivated to carry out policies pushed by $\mathrm{j}$ that are popular (or at least not unpopular) with the aggregate populace if $\mathrm{b}_{\mathrm{n:j}}^{*}>0$. On the other hand, political expenditures must be made for politicians undertaking policies desired by $\mathrm{j}$ that are unpopular if $\mathrm{b}_{\mathrm{n}: \mathrm{j}}^{*}<0$.

In a Nash (1950a,b) optimizing equilibrium, which has been utilized in prior political research such as by Grossman and Helpman (2001), equations (1) and (2) imply that one private agent, or group of agents with common benefits from a particular policy (like a

\footnotetext{
${ }^{4}$ The assumption deduced by von Neumann-Morgenstern (1953) indicated that all agents seek to maximize their utility with respect to any decision that can be measured in monetary units, as implies for any political expenditure $\mathrm{C}_{j}$ a maximization of expected utility $u_{i}=E\left[\left\{P_{s, j} U_{i s} B_{j s}\right\}-C_{j}\right]$, where $U_{j s}$ is the utility to agent $j$ in a future state, $B j s$ is the benefit to the agent in that state, $\mathrm{P}_{\mathrm{si}}$ is the probability of that state occurring, and $\mathrm{E}$ is the expected value operator. Human decision-making is thereby reduced to a maximization of those individual utility functions (Fishburn, 1979) that is based on modeling each person's actions as an attempt to maximize the personal benefits derived from the individual's economic actions in satisfying their consumption preferences (Marshall, 1920). This theory tends to define any activity as a transaction, "encourages a 'businesslike mindset'" and fails to properly incorporate matters of true value to human beings (Economist, $2018 \mathrm{w}$ ). The fact that it is common today for engineers, philosophers, and policy makers to think of human beings as machines (Rees, 2016) follows directly from such theories of humanity. The modeling of human beings as machines that maximize their utility functions through accessing and spending money leads to a macroeconomic conclusion that interest rates balance aggregate savings and investments to efficiently allocate resources for consumption across time to avoid economic cycles (Boehm, 2017). This balance can theoretically be facilitated through financial institutions which funnel savings into investments through financial instruments such as loans. Governments create the legal framework in which the economic utility maximizers operate and facilitate aggregated consumption and investment. However, this system as well as methods of increasing demand through government fiscal and monetary policies create excessive debt that cannot continue and thus lead to the inevitable economic cycle of booms and busts.
} 


\section{Articles}

reduction in business taxation and regulation) will tend to dominate the market for control of government policy. That dominant agent (or group of agents) determined as the one with the highest $\mathrm{c}_{\mathrm{j}: \mathrm{n}}+\mathrm{b}^{*}{ }_{\mathrm{n}: \mathrm{j}}$ according to (1) and (2) is labeled hereafter in this paper as agent $\mathrm{j}=1$ while that Agent \#1's selected politician(s) is specified as $n=1$. This Agent \#1 optimally will only make political expenditures up to the minimum level necessary for

$$
\begin{aligned}
& c_{1: 1}+b^{*}{ }_{1: 1}>c_{j: n}+b^{*}{ }_{n: j} \\
& \text { for all } j>1 \text { and } n>1
\end{aligned}
$$

to hold. Other agents recognizing this fact will not bid at all, so that

$$
c_{j: n}=0 \text { for all } n \text { and all } j>1 \text {, }
$$

and the wealthiest agents (or groups of capitalists) are able to buy politicians with far less funds than the benefits those government leaders supply to them once elected. ${ }^{5}$

The results in (1-4) indicate that agents $\mathrm{j}$ with the most money, such as businesses with the most capital and accumulated surplus value, will be able to control government through enough political expenditures. For example, a policy desired by any agent $j$ that is not perceived to generate any materially negative utility to others (such as the award of a government contract to any particular agent j), $\mathrm{b}^{*}{ }_{\mathrm{n}: \mathrm{j}}=0$, and the wealthiest agent(s) that tend to generate the most benefits $b_{j: n}$ from the particular government action for such policies will tend to be the winner(s) of the political auction. In particular, such agents generating the greatest $b_{j: n}$ from a particular government action have the highest $c_{\mathrm{j}: \mathrm{n}}$ allowed by (1), and, if $b^{*}{ }_{n: j}=0$, they can therefore maximize the $b_{n: j}$ of the political decision makers according to
An Analysis of the Use of Money to Divert the Exercise of Government Power for the Wealthiest

(2). Other agents recognizing that they cannot win the political auction will not bid anything, and the absolute wealthiest agent (or group of agents collectively benefiting from some government policy) will be able to prevail in the bidding contest with very minimal political expenditures.

When a particular policy that is perceived to generate a negative utility among voters is wanted by the wealthiest agent(s), $b^{*}{ }_{n: j}<0$, and (2) indicates that it will cost more to win the political auction. The wealthiest agent(s) will still win the desired government action if that agent has more wealth than any other agent by the amount of the $b^{*}{ }_{n: j^{*}}$ In particular, the agent with the highest $b_{j: n}-c_{j: n}-b^{*}{ }_{n: j}$ will be able to provide the most benefits to any politician $\mathrm{n}$, and the other agents, recognizing this fact will bid nothing. The result is a minimal bid of $c_{j: n}>b^{*}{ }_{n: j^{*}}$ The existence of agents with behavior different from the economic rationality of a Muth (1961) equilibrium in the case of uncertainty about the values of the variables in (1) and (2) will only cause some deviations from the conclusions given in (3) and (4).

Because politicians maximizing their personal benefits in (2) will carry out the policies with the highest $\mathrm{c}_{\mathrm{j}: \mathrm{n}}+\mathrm{b}^{*}{ }_{\mathrm{n}: \mathrm{j}}$, the constraint (1) indicating $c_{j: n}<b_{n: j}$ implies that the agent or agents with the highest value of $b_{j: n}+b^{*}{ }_{n: j}$ will be able to control government actions on any particular issue. On the other hand, the constraint in (1) and the maximization of politicians' net benefits in (2) indicate that an agent cannot have a policy implemented where $-b^{*}{ }_{n: j}>b_{j: n}$. Nevertheless, wealthy agents can overcome even very large negative values for $\mathrm{b}_{\mathrm{n}: \mathrm{j}}$ by colluding to push government

\footnotetext{
${ }^{5}$ This mathematical fact has been proven by Murphy (2019a) using well-established economic theories. That research also showed that politicians, who aren't themselves swayed by the extensive propaganda spread by the capitalist system that is heavily promoted by the wealthy in various ways (including through the education of the young) and can't be bought with campaign donations and other benefits, will not win elections against politicians backed by big money-interests which arm their compliant representatives with funds to engage in overwhelming manipulative marketing of them to the public. This model thus shows why government leaders elected by the people continue to serve the economic elites.
} 


\section{Articles}

policies generating common benefits. For instance, companies can form into business trade groups to pool their resources in order to become the wealthiest Agent \#1, thereby enabling exertion of monetary power over government to have policies implemented that provide more favorable government regulation for their entire industry.

To the extent that there are disagreements among the wealthiest agents about particular policies, compromises can be made to maximize benefits among them at the lowest cost in terms of individual political expenditures through the formation of general special interest groups. For instance, corporations can lobby all together to influence government into reducing corporate income tax rates across the board. The wealthiest agents having the most resources to expend on political investments are thereby able to exert maximum control over government through their political expenditures that supply benefits to leading politicians, who seek to maximize the equality in (2). Inequality (1) indicates that agents' control of government policies is only limited to the extent that the agents generate less benefits than the political spending costs them to win the bidding for politicians through maximization of (2).

These results hold for political systems where government leaders are elected, ${ }^{6}$ as well as in ones where the government rulers are seemingly omnipotent. In particular, the "future of any political party and government depends on 'popular support'" (Economist, 2018s), and "authoritarian governments tend to depend even more on popularity than democratic ones do" (Economist (2018t). For instance, government actions undertaken for the benefit of the wealthy few can sometimes be so unpopular with the public that massive demonstrations and strikes may occur. The government can react to uprisings of any sort with repression by the police and military forces it is empowered to control. However, widespread actions undertaken by the more impoverished majority are early warning signs of a possible open revolution that could expropriate the wealth and power of the richest few. To avoid such events, the rich and powerful typically push their interests only so far and may even reverse course toward enacting government policies more acceptable to the masses.

Political systems with elections can help deflect any inclination of the masses to engage in open revolt by giving voters a chance to choose between different politicians bought to a greater or less extent by big moneyed interests. Almost any system of elections under capitalism results in only two major parties that receive most votes (Dellis, 2013), thus enabling the wealthiest agents to concentrate their political expenditures toward their politicians who are swayed by the money to adopt less extreme positions (Bassetti and Pavesi, 2017). To minimize the extent of the benefits offered to the less wealthy, the political spending of the wealthiest agents is utilized to market the policies they want.

\footnotetext{
${ }^{6}$ The model is valid in any system of voting. In most election systems worldwide, there is an optimizing tendency for political parties to form that generally coalesce into two main parties in order to concentrate voting in sizable enough numbers to have a chance of winning elections (Dellis, 2013). This typical situation merely magnifies the power of the wealthiest agents in the model to buy government power at lower costs, as it isn't necessary for those elites to make political expenditures for any competing politicians not running through the two major parties, which have valuable brand names that lowers their $\mathrm{b}^{*}$ due to their past political spending. In particular, even for voters who are dissatisfied with the two main parties have a strong incentive to strategically vote for the lesser of the "two evils" running on the ticket of one of those parties because a failure to vote for the more preferred of those two raises the chances of the least preferred candidate winning the election (Murphy, 2019b). Such strategic voting further reduces the chances of any third-party candidate winning an election, thus lowering the $\mathrm{b}^{*}{ }_{\mathrm{n}: \mathrm{j}}$ of those candidates further. In addition, for those dissatisfied with the two major party candidates, there is a voting preference for "the devil you know is better than the devil you don't" (Grossman and Helpman, 1996).
} 


\section{Articles}

The persuasive power of adroit marketing can make policies that the majority of the public perceives to be very averse to their own wishes become acceptable over time, thereby positively impacting public opinion and offsetting any $b^{*}$ :j below zero.

The capacity of political marketing to affect public views is especially powerful with respect to government actions which have long-term consequences that are difficult for voters to understand or forecast.

Political marketing can also be utilized to divert voters' attention away from policies wanted by the wealthiest agents but unpopular with the masses. For instance, the policies promised by candidates financed by the wealthy are often diverse enough across noneconomic issues that voter make their ballot choices based on policies that are not relevant to corporations and their rich owners. This political marketing strategy can be especially successful on issues which are on which are divisive among the masses.

\section{Strategies Used to Divert Political Energy into Non-Economic Issues}

Agents are motivated to direct their political spending $c_{j: n}$ into the most efficient marketing strategies in order to minimize those costs incurred in buying government power. One method often employed to offset any negative value for $b^{*} n: 1$ caused by politicians $n$ serving the economic interests of the dominant Agent \#1 is to divert political energy into divisive issues that focuses voter attention into policies with no positive or negative benefits to Agent \#1, For instance, there are many issues, such as non-material ones relating to ethnicity or religious and cultural beliefs, that affect $b^{*}{ }_{n: j}$ but not the $b_{j: n}$ of large corporations. Many government policies on such issues of no concern to most businesses maximizing their profits are associated with entrenched opinions among people reflecting
An Analysis of the Use of Money to Divert the Exercise of Government Power for the Wealthiest

"unconscious" biases and social pressures related to the beliefs of a person's ethnic or other grouping" (Economist, 2017k) that are of little or no relevance to corporations. Cultural preferences based on ethnic and religious groupings can be the overwhelming factor in determining votes because all politicians may be promising economic policies promoted as benefiting all people, including with respect to "better infrastructure, health care and education" (Economist, 2017l).

A focus on non-economic policies can be useful to corporations to distract voters from economic issues providing benefits to corporations and the wealthy. For example, the Democrats" losses at the polls in the 2016 U.S. elections have been at least partially attributed to the widespread unpopularity of their identity politics, which focused on promising benefits to minority groups such as those seeking better treatments based on their race, gender, or sexual preferences, rather than economic issues, and the majority of voters (such as white males and their dependents) may have perceived prejudices against themselves resulting from serving special interest groups (Economist, 2017x). The Republicans effectively utilized this issue of the Democrats' serving special interest groups and thereby drew sufficient votes from the less affluent, who were thereby distracted from the economic programs of the Republicans that more directly serve the economic interests of that party's wealthy contributors and a minority of voters than do those of the Democrats.

Because many policies related to economic issues have uncertain actual longterm effects (such as government providing more benefits to profit-making enterprises that can increase employment and wages), and because politician promises to provide direct short-term economic benefits to voters (like lower taxes and aid for the masses) 


\section{Articles}

may or may not materialize after election, voters can rationally choose to focus on noneconomic issues more likely to be carried out. Politicians who are elected may select whichever side of an issue that is unrelated to the policies desired by Agent \#1, but those politicians representing the interests of Agent \#1 will tend to select policies "irrelevant" to Agent \#1 that they perceive will help win the most votes.

Politicians funded by Agent \#1 may sometimes choose the side of "irrelevant" policies that are not popular among the majority of voters because the positive utility to many voters derived from enactment of such unpopular policies can be more important to many voters than any negative economic effects perceived by voters to result from the government carrying out the "relevant" policies pushed by Agent \#1. In addition, the negative utility to the majority of voters from enacting such policies, which are disliked by most people but are not relevant to Agent \#1, can be more than offset by some perceived advantages to many from the other policies favored by politicians serving Agent \#1 (and thus win the votes of those voters despite their dislike of the policies desired by Agent \#1). A good example of a strategy is provided by the pro-life campaign of the Republican Party in the U.S. that is very important to many people, who therefore vote for that party despite disliking or distrusting the Republicans' probusiness policies.

Other policies advocated by the Republicans but irrelevant to business abound, including those related to the use of birth control, sexual choices, the death penalty, civil and immigrant rights, and aggressive interventions/manipulation in the affairs of foreign countries. The Republican Party in the U.S. won the 2016 election despite that Party's stance on such issues that generated negative benefits for large segments of the voting public, which tended to be for civil rights, equality, and peace, because those issues irrelevant to Agent \#1 were more important to many voters than any tax cuts for corporations and the super-rich that may have been perceived as economically disadvantageous to those people. The Republicans correctly deduced that the majority of voters would perceive more net benefits from their aggregated policies, at least partially as a result of reckoning that there were enough people who perceived sufficient benefits on some issues (like religious doctrine) to offset only minor negative benefits on other issues (like lower taxes for those richer than them). In particular, pro-gun enthusiasts, racists, and nationalists, as well as those against birth control (like many doctrinaire Catholics are) voted for the Republican Party candidates because of that Party's policies which are irrelevant to most corporations and many super-rich individuals. The Republicans' strategy of supporting such policies unpopular with the majority was successful in 2016, as can be mathematically shown with the following proposition which indicates how a political marketing strategy makes two unpopular policies a winning combination.

\section{Proposition:}

Many political interest groups $j=g$ focused on non-monetary issues that are unpopular with voters expend large amounts of money on campaign contributions and advertisements to persuade politicians to take government actions $g$ wants. Through sufficiently large political expenditures $c_{g, h}$ for enough politicians $n=h$ to make $g$ the dominant agent on the policy $g$ desires through the highest $c_{g, h}-b^{*}{ }_{h: g}, g$ may be able to motivate $h$ to pursue $g$ 's desired policy. Corporate agents $j=d$ indifferent to $g$ 's unpopular non-monetary views may optimally contribute to $h$ if the non-economic policies advocated by $h$ serving $g$ result in $d$ being the dominant agent at the lowest possible cost $c_{j: n}$. 


\section{Articles}

to $d$ via the aggregated $c_{d: h}+c_{g: h}-b_{h: d}^{*}-b_{h: g}^{*}$ that satisfies (1) and minimizes (3). This outcome may hold even if the pro-business policies wanted by $d$ as well as the non-economic government actions desired by $g$ are separately unpopular with the majority of voters but are each preferred by some voters to different degrees. In particular, the impact of combining the policies wanted by both $d$ and $g$ results in a plurality of voters who have a relatively strong preference for. one of the policies and only a mild dissatisfaction with the other.

The political successes of the National Rifle Association (NRA), which greatly outspends the anti-gun lobby (Kessler, 2018), supply a good example of the success of such a winning alliance with the pro-business lobbies through Republican politicians that can be defined to be $j=g, j=d$ and $n=h$, respectively. The Republican Party, which was heavily financed by both separate groups, advocated for both pro-gun (pushed by agents g) and probusiness policies (pushed by agents $\mathrm{d}$ ). The policies desired by g apparently were strongly desired enough by a minority of voters who moderately disliked d's views, but the latter disliked policies of $\mathrm{d}$ were less important to those voting for $\mathrm{h}$ than were their preference for g's policies. This alliance is also indicative of other non-economic policies followed by pro-business Republican candidates, such as with respect to abortion restrictions and a powerful military posture.

However, if the corporations and their wealthy owners ever perceive such alliances to no longer be optimal, they can have the politicians they financially fund take a more neutral or even opposite position on the issues promoted by $\mathrm{g}$. In particular, if the policies advocated by agent $g$ here were ever to be so disliked by voters such that
An Analysis of the Use of Money to Divert the Exercise of Government Power for the Wealthiest

$\mathrm{c}_{\mathrm{d}, \mathrm{h}}+\mathrm{c}_{\mathrm{g}, \mathrm{h}}-\mathrm{b}_{\mathrm{h}, \mathrm{d}}^{*}-\mathrm{b}_{\mathrm{h}, \mathrm{g}}^{*}$ does not make corporate agents $\mathrm{d}$ dominate at the lowest political expenditures for $d$ in (3), then either h's stance on g's desired policy would change or d would optimally choose other politicians to support. The various political positions of Trump, the current leader of the Republican Party leader who has flip-flopped not only on political issues over the years but also on the politicians and parties he supports, is illustrative of this phenomenon. Even some policies that specially serve only a minority of corporations might become so unpopular among voters due to adverse events that the interests of those few companies are no longer supported by other corporate agents, pro-business politicians, and parties serving their wealthy benefactors. The withdrawal of financial support for some climate-change denying think tanks as a result of adverse publicity (Watson, 2014) is illustrative of this type of development.

Even when a political marketing strategy by the most pro-business mainstream party like the Republicans in the U.S. fails, the result tends to be merely electoral victory by another pro-business party like the Democrats. The different representation of special interests by each of those parties serves to divert voter attention toward non-economic issues and thereby distract the public from any material difference in the degree of pro-business policies adopted by the two main parties financed by the wealthy. ${ }^{7}$ In addition, the minor differences in the two parties' stances on probusiness issues are useful for funneling some of the dissatisfaction with the current political situation and policies into a competitive vote for the "lesser evil" capitalist party.

Co-opting special interests that are of mixed, little, or no benefit to corporations and

\footnotetext{
${ }^{7}$ With electoral systems tending to concentrate the exercise of government power through two main political parties (Peeters, Saran, and Yueksel, 2016), wealthy special interests tend to concentrate their political expenditures to win influence over government policy through those two parties (Bassetti and Pavesi, 2017).
} 


\section{Articles}

the wealthy is widely employed by businessfunded politicians across the world. For instance, political parties are focusing ever more on "cultural" or religious issues as their voters have become increasingly frustrated by the corruption and failures of previous politicians to economically serve the masses (Economist, 2018h). European mainstream parties widely adopt government policies restricting immigration, as doing so is popular among the lower classes (Economist, 2018aq) due to cultural biases and perceived personal benefits associated with restricting the supply of labor (that can increase the employment and wages of existing voters) While restrictions on the supply of labor may adversely impact the wealthiest agents by increasing the labor costs of businesses, which must offer higher wages as a result, many rich people, who have significant ownership of and control over corporations, have their own cultural biases against importing foreigners.

In addition, business expenditures for purposes of direct benefit to society but not directly increasing profits are utilized worldwide by corporations to help their image among voters, as such "socially responsible" behavior causes companies and their financed politicians to be viewed more favorably, thereby increasing the $\mathrm{b}^{*}{ }_{\mathrm{n}: \mathrm{j}}$ of those agents $\mathrm{j}$ among politicians n. Such indirect political expenditures $c_{j: n}$ divert public attention from any relatively adverse effects of other activities of j. Such corporate social spending can also help politicians $n$ by enabling governments to use less of taxpayer money for such purposes. In India, corporate expenditures for socially constructive purposes are even required by law that may be made for projects wanted by government leaders (Economist, 2017ag), who may therefore adopt tax and regulatory policies to benefit those agents $\mathrm{j}$ spending money for the projects most desired by $n$.

\section{The Impact of Restrictions on} Political Spending

Binding maximums placed on political spending can theoretically modify the outcome in the market to buy politicians and government power. However, as explained here, existing limits on political investments by agents tend to be ineffective. It is unclear if it is even possible to implement caps on political expenditures that would inhibit the buying of government power, as this section indicates. For instance, political expenditures independent of any politician or political party can be made to promote government policies favorable to any agent(s) j. Corporate advertisements and public relations spending, business-funded advocacy groups like think tanks, and donations to educational institutions or charities that generate goodwill for businesses and the wealthy or promote their interests influence $b^{*}{ }_{n: j}$ and hence reduce the expenditures $c_{j: n}$ required in (3) to buy government power. Limits on campaign contributions tend to merely drive political expenditures into different forms of spending that indirectly increases the chance of electoral victory for those candidates favoring the policies wanted by an agent engaging in independent promotions.

Any binding prohibitions on political expenditures (such as laws against large political campaign donations) will have an effect on (3) and (4) only if they restrict Agent \#1 from making the maximum political expenditures specified in (1) in some form. In particular, if

$$
\begin{aligned}
& \mathrm{M}_{1: 1}<\mathrm{b}_{1: 1}+\mathrm{b}_{1: 1}^{*}-\mathrm{m}_{\mathrm{j}: \mathrm{n}} \\
& \text { for all } \mathrm{n} \text { and } \mathrm{j}>1
\end{aligned}
$$

where $M_{i: n}$ is the binding maximum political expenditures of the subscripted agent $j$ for politician $n$, and $m_{j: n}$ is the lesser of $M_{j: n}$ or $b_{i: n}-b_{n: j}^{*}$, then (3) and (4) no longer hold for the dominant agent $j=1$ that would exist 


\section{Articles}

without the binding caps. Instead, if (5) holds, then the agent(s) with the highest mj:n would be the new Agent \#1, and (3) and (4) would be valid for the newly defined agent $j=1$ with the binding caps. This new Agent \#1 is the one with the highest benefit $\left(b_{j: n}\right)$ from buying a politician net of the cost $\left(\mathrm{b}^{*}{ }_{\mathrm{n}: \mathrm{j}}\right)$ to purchase popularity for that politician subject to the cap $\mathrm{M}_{\mathrm{j}: \mathrm{n}}$.

Equation (5) could theoretically hold in countries where there are special laws against some organizations making campaign contributions that aren't as restricted as for other agents or groups of agents. For example, legal caps may be binding on corporations but not on human beings, or equally limited but with $\mathrm{b}^{*}{ }_{\text {n:j }}>\mathrm{b}^{*}{ }_{1: 1}$. Note, however, that the newly defined Agent \#1 may be a group of agents who can circumvent individual caps by acting together to make political expenditures that sum to more than the binding limit on any other agents to serve their common interests.

Colluding agents can become the collective Agent \#1 if they make political expenditures for politicians supporting that group and agree to share the benefits from successfully winning the favors of the chosen candidate(s) in a manner considered fair by all members of the group (as in the case of individuals benefiting from lower personal tax rates). For instance, a group of agents $\mathrm{j}$ could conspire to make political expenditures $c_{j: n}$ proportional in size to their relative benefits $b_{j: n}$, and any such group will be able to optimally outbid all other agents $j=2$ to J, thus becoming the collective Agent \#1. In the latter case, (3) and (4) would hold for this communal Agent \#1.

Collusion among agents trying to influence government policy is costlier when the agents are disparate and not well organized (Zardkoohi, 1988). In particular, the costs and benefits of lobbying among a large number of agents may be spread too thinly to motivate them to contribute to the cause,
An Analysis of the Use of Money to Divert the Exercise of Government Power for the Wealthiest

as there are larger incentives for "free riding" when there are many other beneficiaries who can be relied upon to make contributions to a common cause (and contributions by any agent are useless if other allied agents try to free ride). As a result, such collusion is more likely among concentrated set of agents such as the wealthiest along with the corporate industry and business groups they control. Thus, despite limits on individual agent contributions, it is difficult for masses of less affluent individuals with few financial resources to successfully conspire to become Agent \#1.

Regardless, it is questionable whether any existing caps on political expenditures are truly binding in practice. For instance, while there are some limits on the size of direct campaign contributions by organizations and individuals in the U.S., there are no caps on spending by a candidate for office from his/ her personal wealth. As a result, (5) did not apply to the 2016 Presidential campaign of Donald Trump, who had billions of dollars in personal wealth that he could have used to outbid other candidates (although he actually perceived a need to spend less than $\$ 100$ million of it). Other candidates may have felt powerless in the face of this fact, thus resulting in outcomes more similar to (3) and (4). Nevertheless, some agents made donations to other Presidential candidates (including other ones running for the Republican nomination) because they perceived $b^{*}$ n:j to be sufficiently negative for Agent \#1 (i.e., those supporting Trump, including Trump himself) compared to those other agents.

Even more important than candidates spending their own money for political campaigning, there exist various vehicles in the U.S. for circumventing caps on campaign contributions to politicians. For instance, Political Action Groups (PACs) which serve particular businesses or special interests 


\section{Articles}

have less restrictive limitations on campaign contributions to politicians, SuperPACs are allowed that pool agent contributions to enable virtually unrestricted political spending to advocate for or against politicians as long as they are made independently of any political party or candidate. The 2010 decision by the U.S. Supreme Court in the case of Citizens United vs. FEC has been useful in further facilitating circumvention of limits on political expenditures by any agent in the U.S. without any disclosure (Hasen, 2012) that might otherwise reduce the effectiveness of the political marketing (Dowling and Wichowsky, 2013). In the most recent elections, over twice the $\$ 2$ billion in declared political spending in the U.S. is estimated to have been made without public declaration of the expenditures (Economist, 2017ae).

Although there are rules and limits on formal direct lobbying of government in the U.S. such as those implemented by President Obama while he was in office, those are also easily circumvented (Economist, 2017w). In addition, even foreign agents, whose own lobbying activities may be subjected to more restrictions and disclosure requirement in the U.S., may obtain influence over the U.S. government by providing benefits through business dealings that are lucrative to U.S. corporations, which may then lobby for their mutual benefit. Moreover, marketing any particular desired government policies through non-profit organizations such as think tanks and educational foundations have never been subject to any restrictions (Wang and Qian, 2012) and unlikely can be. Thus, there are effectively no truly binding limits on the amount of corporate money that can be used to market their desired policies and politicians to influence elections and gain power in the U.S. other than the constraints given in (1) and (2).
Perhaps the best-known case of large amounts of money spent to promote corporate interests is the campaign to deny that climate change is caused by fossil fuels. The huge oil company ExxonMobil by itself has long been giving $\$ 10$ million annually to think tanks, industry associations, advocacy groups, and other non-profit organizations, as well as to politicians, who continue to deny the existence of climate change science and advocate against policies that create incentives to reduce fossil fuel use (Negin, 2016). More recently, 140 foundations have given $\$ 558$ million to various climate denial organizations, with most of the donations being supplied by publicly unidentified donors (Fischer, 2013).

Such political investments by fossil fuel companies have likely been instrumental in influencing public opinion, thereby resulting in the election of many politicians who advocate against increased regulation or taxation of fossil fuel use. Although attorney generals from at least two states (New York and Massachusetts) have filed lawsuits for fraud against ExxonMobil for that company's promotional denials of climate change despite evidence that firm knew it was contributing to global warming as early as 1977 (Hasemyer, 2017), the outcome of such court cases is very uncertain.

In the meantime, the election of a President and Congress in the U.S. that advocated for the interests of the fossil fuel companies in the 2016 electoral campaign has already resulted in government policies even more beneficial to carbon-emitting firms in 2017. The persuasive promotion of government policies desired by energy firms has been targeted on Republican voters (Economist, 2018c), as the corporate and wealthy financial backers of the Republicans in power have succeeded in pushing the elected government to concentrate on promised but uncertain 


\section{Articles}

long-term benefits from tax cuts to those financial backers of the Republicans in power. A political marketing strategy of focusing on the short-term and ignoring long-term impacts has long been utilized by politicians (Das, 2018)

In some nations, there may be more binding caps on some political expenditures than exist in the U.S. For example, in France direct campaign donations and political advocacy spending are very limited, and, partially as a result, there was a recent election of politicians and a new party with no initial funding or recognition (Economist, 2017ac). While such limitations on political expenditures can appear to be rather binding (Meunier, 2017), it is unclear if it could ever be possible to cap spending to influence voters and politicians through money used to fund research, education, and promotion of views on particular issues of relevance to agents. Agents can thereby affect government actions on matters that affect them like government regulation, taxes, and economic policies. The fact that the recently elected French leaders and their new party are clearly pro-business is likely no accidental outcome.

Blanket limitations on political campaigning can help existing government leaders stay in power, thereby enabling political spending to be focused on only existing government leaders because such caps inhibit the ability of other politicians to gain political influence (Economist, 2018e). In particular, politicians already in office can utilize their position to market the policies they push. In addition, already elected politicians and their political agendas pushed by wealthy agents prior to their election would already have helped persuade the public through the prior political expenditures by agents to promote them. Such political marketing creates brand name recognition that alone provides an advantage of incumbents over challengers (in terms of a
An Analysis of the Use of Money to Divert the Exercise of Government Power for the Wealthiest

higher $\mathrm{b}_{\mathrm{n}: \mathrm{j}}^{*}$ for an already elected government leader compared to lesser known politicians who bring greater uncertainty and risk that is often not wanted by voters). In political systems with more government leaders, the same conclusions hold, as spreading power among more government leaders merely results in wealthy agents using their monetary power to influence more politicians (Economist, 2018g).

Any agents anywhere may obtain influence over government by locating their commercial operations in areas or countries that provide benefits to the voters of politicians in the form of increasing local investment and employment. Those benefits to voters make politicians $n$ more popular, (i.e., have a higher $\mathrm{b}^{*}{ }_{\text {n: }}$ ) if they undertake government actions that the agents want. The ability of businesses and the wealthy to engage in commercial activities that affect people's lives (such as through operations which provide investment and employment) that can be made in areas or countries where governments offer more benefits (such as with respect to regulation and taxes) makes attempts to inhibit the worldwide buying of government power nearly impossible.

Companies routinely and legally affect government policy at all levels through locating their business activities in areas that are governed by political leaders who promise subsidies and other attractive benefits to the business even at the local government levels inside a single nation (Economist, 2017z). To the extent that companies invest in areas that would be costlier to them without the government actions they desire, they are making political expenditures $c_{\mathrm{j}: \mathrm{n}}$. Any extra costs associated with such investments (such as those that wouldn't be incurred without regard to the government policies they induce) would represent a form of political spending which would be difficult to limit both within a country and internationally unless 


\section{Articles}

governments were unified across the world. It is well-recognized that the jobs provided by large corporations alone motivates politicians to undertake policies to help them, although especially infamous actions by those companies can result in such bad publicity that governments occasionally do take actions that adversely affect them (Economist, 2018q).

Thus, existing government regulations seem to be impotent in restricting the control of government power by rich elites. It is unclear whether binding caps on political expenditures can even be designed to restrict rule by the wealthiest agents within capitalism.

\section{Conclusion}

This paper analyzes how wealthy "people" are able to control government policy in modern times. That money is employed through adroit marketing to win popular support for policies which serve the interests of the wealthiest few. Limitations on political spending are shown to be impotent in hindering the processes involved in money purchasing government policies at the lowest possible expense and hence highest profits.

The formal proposition made in Section III indicates one subtle and particularly effective marketing tactic sometimes utilized by the wealthy to attain their political goals. In particular, it is there demonstrated mathematically how particular special interests can be harnessed in a way which diverts popular discourse into choices which do not adversely impact the wealth of the elite. The support provided by wealthy agents to political candidates who promote divisions among those with less money to take jobs, rights, and freedoms away from other groups of people diverts political energy away from policies that might impair the economic interests of the wealthy.

Although it seems humanly natural for a plurality of voters to eventually become resentful enough of being manipulated and exploited to cause a revolution via elections that could legally transfer control of government powers to all the people (and not just the rich), those forces can be redirected into divisive issues which are unrelated to the economic interests of those with the most money. The rise of fascism as a response to popular dissatisfaction with the capitalist economic system and concentrations of wealth in the hands of the few may be explained through this mathematical proposition. This hypothesis might be tested by examining the political investments by wealthy agents providing funding to both fascist and more mainstream political candidates/parties/groups promoting the interests of the wealthy (that would indicate the relative magnitude of the different political investments in alternative political climates as well as the return on such expenditures).

Illustrations of many different methods used by the wealthy elites to control government power across the world are provided in Appendix I. Appendix II indicates the obstacles to a government for all the people. In particular, the latter appendix indicates that government power may continue to reside with the wealthy elite as long as voters continue to be persuaded or manipulated via political marketing expenditures to allow their choices at the ballot box to be bought by the trillions of dollars which wealthy agents have to expend politically to protect their wealth. ${ }^{8}$

\footnotetext{
${ }^{8}$ This paper shows that a maintenance of the capitalist world order in some form seems to be virtually inevitable if the purely utilitarian theory of individual economic behavior is an unchangeable law of nature. This theory essentially modeling people as mere reactive robots can be derived from the philosophy of determinism that makes all events and interactions a function of prior states of the world. However, this theory ignores the reality of human beings having the capacity of collapsing all quantum states of superposition into being across time and thus having free will, thereby resulting in human beings who are intrinsic to determining which of the multiverse of possibilities that occur (Murphy, 2011). The latter scientific fact invalidates conclusions
} 
Articles

\section{Appendix I}

\section{Worldwide Applications of Buying Government Power}

The model developed in this paper provides a framework for understanding the control over governments exercised by agents with the most money. This appendix uses political phenomena reported in the mainstream press to illustrate the applicability of the model in many different circumstances that exist worldwide.

The 2016 election for U.S. congressional representatives provides one simple example of the power of money to buy elections. In those races for control of the U.S. House and Senate in which the Republicans won majorities, aggregate direct contributions to the Republican candidates exceeded that of the competing Democrats in the aggregate, and the candidates with the most campaign donations won $96 \%$ and $94 \%$ of the elected seats, respectively, in 2016 (Balcerzak, 2016). These results are consistent with the effects of any lower $b_{n: 1}^{*}$, for the winning
An Analysis of the Use of Money to Divert the Exercise

of Government Power for the Wealthiest

Republican candidates best serving the collective wealthy Agent \#1 being overcome with sufficient political expenditures to enable the Republicans to win a majority of seats in Congress. $^{9}$ Although the Republicans promised more benefits to businesses and the wealthy (through lower taxes and regulation), their larger pool of money available for political spending (including in the past) resulted in them defeating the capitalist Democratic Party, whose policies were also pro-business but offered relatively more direct economic benefits to the majority of Americans.

The wealthy elites of the collective Agent \#1 group supporting the Republicans in 2016 include non-voting U.S. business organizations as well as a minority of voters who are rich. Those agents had been making political expenditures in favor of the policies they wanted for many years, and that spending prior to 2016 appears to have influenced the most recent nationwide election in the U.S. by raising $b^{*} n: 1$ for the politicians $n$ promoting those policies. In particular, the size of the $c_{1}$. needed in 2016 to neutralize the negative $b^{*}{ }_{n: 1}$

based on the economic theory of humans as mere machines engaging in reactive processes in a deterministic world with just random uncertainty, unless people are made to believe that theory. Communist systems of political economy that transfer ownership of capital with public possession for the benefit of the human beings themselves in the aggregate (Marx, 1848) would seem to the natural human order of political economy, as the latter social systems are similar to those prevalent thousands of years ago among most people on earth and are therefore the ones in which human beings evolved to live most happily, cooperatively, and productively (Murphy, 2011). The increasing public and employee ownership of corporate stock along with elections themselves represent a movement toward a collectivist system, albeit currently in a rather unequal fashion which is unnatural to the evolved human desire for each to make the effort to try to contribute as much as others to society and share no less in the spoils of their labors over time (while each person feels a natural resentment at receiving a lower share and at others not making the same effort to contribute to society). Increasing awareness of these facts can potentially slowly push the world peacefully in the direction of communism through political democracy and common ownership of the means of production, as has been the trend over the last few centuries despite the self-destructive forces of capitalism arising in the form of fascism in desperate attempts to stave off rapid advances to a natural egalitarian democracy. The natural tendency of people to engage in political activism for the common good (Klar and Kasser, 2009) may be a force potent enough to overcome all the money in the world (as may be necessary to defeat the power of the wealthiest few).

${ }^{9}$ Agents seeking maximum political influence have to win over not only the President but also a majority in the U.S. Congress, and so large campaign donations are typically made to many congressional candidates of the two major parties in the U.S. (i.e., the Republicans and Democrats). Strategic political expenditures by business interests to both major political parties to get them to both serve those interests to a more or less degree have a long history going back to the $19^{\text {th }}$ century (Copeland, 2000). The model developed in this paper indicates that larger expenditures would be given to politicians with a larger chance of winning for the same level of political spending, thus explaining why large corporations and wealthy individuals historically have contributed more to candidates of the Republican Party, which tends to advocate policies that are friendlier to business and the wealthy but less so than the Libertarian Party, which receives very little funding because it doesn't have the Republican brand name that therefore contributes to an even lower $b^{*}$ n:j for that party. 


\section{Articles}

for the Republican candidates $\mathrm{n}$ supporting the policies of the collective Agent \#1 was lower than in prior years because of the longterm effects of past political expenditures of all types that effectively raised their $b^{*} n: 1$ over time.

A. Marketing to Persuade the Public to Support the Politicians Financed by the Rich

A large amount of political spending is designed to directly affect voter opinions and election choices, including people's decisions to register and cast a ballot. Because virtually all politicians running for office make campaign promises that they and their policies will serve the majority of voters best (at least long-term), the persuasive power of marketing funded by large political expenditures can be decisive in determining election outcomes. It is easier (and cheaper) to convince voters to cast ballots in favor of politicians advocating particular policies providing relatively more benefits to a select rich few if there is some uncertainty as to the long-term economic effects of their policies on all the voting agents. For instance, lower regulation and taxes for businesses as well as for the wealthy along with reduced social spending (and lower government taxes and fiscal deficits) may bring long-term benefits to all agents in the form of higher economic growth in the future that eventually trickles down to other agents, even though the evidence supporting such long-term benefits is weak (Economist, 2017f). Some political spending advances extreme positions on issues in order to rally more support that may not be popular among the majority initially but that eventually pushes public opinion and more moderate politicians closer to those points of view through the persuasive power of those marketing expenditures (Economist, 2017aa).

Actual past experiences may be found or manipulated to market policies that would otherwise by unpopular among voters. For instance, over the last few decades, the share of national wealth and income going to the most affluent few has been higher when the Republicans have been in power in the U.S. (Shapiro, 2017). The Democrats are able to use such information to persuade many voters to cast ballots for them to reverse that trend which is adverse to the average voter. On the other hand, there has been a threefold higher increase in the real wages of college graduates in the U.S. over the last four decades compared to the real wages of high-school dropouts (Economist, 2017h). Given that there has been a reduction in taxes and regulation for businesses during that time interval, the Republicans can convince many educated individuals to vote for them if they perceive maintenance or even intensification of those past policies by the Republicans will continue the prosperity of the more educated. ${ }^{10}$ The recent election of Trump to be President of the U.S., along with a Congress that is controlled by the Republican Party, reflects

\footnotetext{
${ }^{10}$ The past trend toward policies and politicians favoring a more "highly" educated elite that tends to be affordable only by those with sufficient money (thereby preserving their power through a college degree "union card") may reverse itself. For instance, Adee (2017) has hypothesized that, in the far future, free markets will move toward making most goods and services virtually costless, thus resulting in societies advancing to a future situation where there is little or no payment for goods and services produced by automation, and people will therefore compete for monetary compensation only with respect to customized work, which may also be motivated by winning social points or recognition, fame, and popularity by producing the best such skilled crafts. While the skills for such societies or any other may depend somewhat on education, automation may also make the skills and knowledge needed to succeed virtually costless and thus less elitist, as with online software employing artificial technology that aggregates masses of information on individuals to enable computerized simulations of customized personal tutoring, which is the most effective form of teaching, although the best tutoring is still provided by human teachers (Economist, 2017o). There are already shifts in political sentiment toward relatively more access to education for poorer members of society, as in South Korea today where there is extreme resentment for the educational privileges of the wealthy elites (Economist, 2017q).
} 


\section{Articles}

the success of the Republican slant on the past that has long been well promoted by the higher political expenditures of businesses and richer individuals who gain the most from them. ${ }^{11}$ The attempt by the U.S. Democratic Party to win the political contributions and votes of those relatively disadvantaged by those policies failed in 2016. ${ }^{12}$

A large amount of political information is spread by the media. Public opinion may be strongly shaped by entertainment programming alone that can endow particular people, organizations, and views of the world with a favorable or unfavorable image (Economist, 2018ab). In countries where the public airwaves and other communication mediums (such as the internet) are given to private companies (as is the case in much of the world), the media is inclined to slant their news reporting and programming to be more pro-business for the political benefit of their own owners, who gain from lower corporate taxes and regulation. Some owners of large media firms specifically direct the reporting bias of their companies (Bozick, 2018). Since the profit-seeking media also seek to maximize their subscription and advertising revenue by attracting larger audiences (Dyck, Moss, and Zingales, 2013), those firms are actually making political expenditures to the extent that dissemination of other information might be more popular and attract larger audiences.
An Analysis of the Use of Money to Divert the Exercise

of Government Power for the Wealthiest

In addition, media businesses are dependent on advertising revenues, most of which is paid by large corporations, and so the advertisers can put implicit or explicit pressure on the media firms to promote a more pro-business agenda, which is also motivated due to the concentration of media ownership by corporations and the wealthy (Herman and Chomsky, 1998). In particular, companies can switch their purely commercial marketing expenditures away from particular media companies which do not promote a sufficiently favorable image of business and the rich. Firms, which make their marketing spending to media organizations that put businesses in a more positive light, are effectively engaging in subtle political spending to the extent that advertising of their products and services is less effective than it would be if directed through other media. Companies involved in mass communication can also be pressured by the advertising of well-funded political organizations, which, in the case of political parties like the Republicans and the Democrats in the U.S., want programming with a largely pro-business agenda for the benefit of their corporate financial backers.

The particular evidence and point of view of any corporation can also be directly disseminated by the company itself. For instance, companies endow their public affairs departments with a large amount of resources to promote their message through the media

\footnotetext{
${ }^{11}$ New information about the benefits of a policy can result in a change in the perceived benefits of alternative policies to different voters that can affect the relative size and sign of $b^{*}{ }_{n: j}$ for various politicians representing those agents. For example, more recent experiences indicate relatively less advantages for college graduates as growing information technology and computerized artificial intelligence power is reducing the demand for those with a university diploma, with this effect being analogous to that of the effect of the Industrial Revolution on the benefits to those who had developed abilities through personal investments in craft apprenticeships being reduced at the expense of unskilled labor due to increasing automation which did not require any craftsmanship (Economist, 2017a). As a result, politicians who enact policies that create relatively more benefits to those without college diplomas (and reduced government spending for higher education) might be preferred by voters if those politicians promote the advantages of such policies to a majority of people. The large number of votes by those without college education for the Republican Party that ran on a platform which was largely not favorable to the academic elites provides some evidence of such a trend.

${ }^{12}$ Changes in the economic and political status of the aggregate electorate can affect the overall receptiveness of voters to marketing particular government policies in the U.S. and elsewhere. For instance, the increasing size of the middle class in Latin America is contributing to a greater acceptability of less government interference in the economy (Economist, 2018d).
} 


\section{Articles}

as well as through their own publications and commentary (Economist, 2017u). Corporate sponsored research, including through academic and not-for-profit institutions dependent on corporate donations, is biased toward promoting their products which may provide little or no true benefits to consumers and can even be harmful, as is well illustrated in the food industry (Fleming 2018).

Besides impacting public opinion, businesses also influence government leaders directly through lobbying their own biased provisions of information (Economist, 2017ah, 2018aa). They have well-recognized "political power to shape the rules in their favor" (Zahn, 2019). Government cost-cutting can enhance this power of corporations if the associated reductions in fiscal research budgets reduce the ability of government staff and agencies to conduct their own independent investigations into the advantages and disadvantages of different policies, thus making political leaders ever more dependent on the biased research and information provided by the lobbyists of special interest groups, which have more resources, and which thereby can slant information to promote policies beneficial to them (Economist, 2017ai). Former political leaders are often hired by companies to help in government lobbying (Millies, 2015), and existing leaders are able to see the future job benefits that exist from using their current power to serve corporations. It is well recognized worldwide that the U.S. has a "money-driven political system" where large corporations have strong political connections that enable influencing the exercise of government power (Economist, 2018b),

More ethically questionable tactics are also sometimes utilized to influence the political process. For instance, firms specializing in marketing for others are often hired by companies to develop and implement strategies to promote well-funded politicians that are sometimes based on total lies (Economist, 2017t). Allegations that create negative perceptions of some candidates (and even "sham" criminal charges) are not infrequently made to increase the relative popularity of other politicians (Economist, $2017 \mathrm{~m}$ ). Money can also buy intimidation of poorer voters to influence particular electoral outcomes beneficial to the wealthy but adverse to the poor (Schmidt, 2017). For instance, corporations gather incriminating information on their employees relating to their personal lives and employ disciplinary actions against legal political activity, as well as offer cash bribes to buy off opposing leaders (Economist, 2018z).

B. Examples of Collusion among Agents to Influence Government

Formal collusion among agents to make political expenditures together is widely utilized to influence government. In particular, there are many existing organizations which take donations from various agents with allied interests that aggregate political lobbying expenditures for their common benefit.

For instance, collective beneficiaries of a government policy or contract award often make their expenditures through their donations to a trade association, which advocates government policies in support of businesses in particular industries, and to other non-profit political organizations which themselves received an estimated $\$ 173$ million in donation in a recent years from the 300 largest corporations in the U.S. (Beckel, 2017). PACs, which aggregate donations from employees of particular companies seeking to advance the goals of their employers to thereby enhance their own careers, represent other colluding groups of agents to influence government policy relevant to their firms. One group of agents, the National Association of Manufacturers (NAM), sells information to employers to enhance those agents' direct 


\section{Articles}

marketing of politicians to their voting and contributing employees (Bombardini and Trebbi, 2011). The Business Roundtable has a long history of lobbying against many different types and forms of regulation as well for corporate income tax reductions (Ritholz, 2019).

Perhaps the largest single colluding group is the United States Chamber of Commerce that makes political expenditures for the benefit of the member businesses. That association promotes lower business taxes and less regulatory costs for businesses in general. In addition, like many non-profit organizations dependent on contributions to it for their existence, that association focuses more on policies which benefit those donating the most to it. For instance, the Chamber pushes for the business-friendly policies of greatest benefit to the largest donors, which once included tobacco firms tying donations to advocating against anti-smoking policies worldwide, and which today include oil, gas, and coal companies that appear to have succeeded in having the Chamber advocate for their interests over alternative energy sources (Broadwin, 2015). Smaller companies may give to their local Chamber of Commerce, which promotes their interests in local government affairs, but they also benefit from collusive donations that can add up to significant political influence at the national level to maximize the after-tax profits of all businesses. $^{13}$

C. Various Ways Agents Use Money to Exert Control over Government Policies Worldwide

The trade of government actions desired by private agents in return for benefits to
An Analysis of the Use of Money to Divert the Exercise of Government Power for the Wealthiest

ruling politicians occurs in numerous ways internationally. For instance, corporations often make outright bribes to influence government policies, including across countries (Economist, 2018a). In Mongolia, mining licenses and real estate deals, as well as government posts, are explicitly bought (Economist, 2017i). Many bribes are made subtly such as through provision of subsidized or free services to politicians and political parties (Economist, 2018u). European and American firms tend to use third parties to bribe government officials to win contract awards (Economist, 2018k). International banks hire relatives of clients to win their business (Robinson, 2019). In Thailand, loans to politicians whose government power is sought may be made to avoid bribery laws (Economist, 2018f). State-owned banks are especially useful to distribute funds to businesses owned by politically connected cronies (Economist, 2018r).

Politicians in power supply many kinds of hand-outs or other benefits to reward their supporters and motivate continued support (Economist, 2018m). In South Korea, there have been many cases of illegal bribery of government officials by large corporations (including through gifts to politicians' family members and donations to charities they favor or control) that have resulted in judicial leniency and Presidential pardons (Economist, 2018j). In the U.S., Presidential pardons themselves may be effectively bought for people sentenced to prison for illegal business activities (Schweizer, 2016). Political patronage is frequently provided by contract awards to businesses, including across borders as evidenced recently by

\footnotetext{
${ }^{13}$ Within governments, collusion also sometimes exists in the form of coalitions that are optimally formed among elected politicians through bargaining to maximize summed benefits across supporters for particular policies (Bradford and J. Kagel, 2015). This sort of collusion that may be more doable on broader economic policies within parliamentary systems with more than two political parties (Economist, 20180) represents a further layer in the process involved in agent groups winning over government leaders to policies they support. However, as Peeters, Saran, and Yueksel (2016) and Bassetti and Pavesi (2017), have shown, political parties compromising on a common set of policies are optimal under either eventuality.
} 


\section{Articles}

the 2017 visit by Trump and his entourage of corporate backers of many contracts for armaments and infrastructure spending by Saudi Arabia (Goldstein, 2017). ${ }^{14}$

Government jobs themselves are often provided to supporters of politicians who have won elections (Economist, 2017n). A typically "revolving door" is associated with former government leaders (include prior prime ministers) receiving benefits in the form of lucrative jobs in companies which benefited from the policies they enacted while they were in office (Economist, 2017ab). "Authority is handed down and money up" in "the whole elite nexus of business and political families' in Cambodia" (Economist, 2018n).

Once elected or chosen, government leaders themselves often spend state funds to help themselves or their cronies to win future elections (Economist, 2017v). In the U.S., it is not uncommon for government leaders to redistrict voting areas to the advantage of an elected party (Economist, 2018I). It is also becoming increasingly apparent that appointed bureaucrats like those in the U.S. Federal Bureau of Investigation (FBI) use their positions to affect public opinion and electoral outcomes through their selective disclosure of information and legal actions (Martin, 2018). Governing officials in some countries enact much more blatant laws and restrictions on political activity to control election outcomes (Economist, 2018v). Government leaders sometimes take actions against media firms to inhibit unfavorable publicity that can even include closing them down or having them acquired by more friendly companies (Economist, 2018p).

While charges about politicians using their power to give economic benefits to themselves, their family, and others can negatively impact the popularity of particular politicians, the interests of the "bourgeoisie" is often still served by merely promoting alternative candidates who do not have the detrimental political baggage associated with being part of a system of political corruption (Dunkel, 2071). Outsiders with no connections to discredited politicians can promise to clean up corruption and serve the people to win votes but then turn out to be even more corrupt and compliant to big money interests that even include organized crime (Economist, 2017y).

The model developed in this research also applies to exercising influence over the policies favored by individual nation members of international groups. For instance, China has been making large expenditures and investments in Africa that seem to win political favors in many African nations, which for example, are influenced by such spending to vote on the same side as China in the United Nations (UN) on matters brought before that international body (Economist, 2017r). In the Maldives, China has supplied loans to the government for large public works projects, which provided substantial room for monetary

\footnotetext{
14. Corporate meetings with the U.S. President alone (that can create goodwill and regulatory relief) have been shown to be followed by increases in shareholder value (Economist, 2017b). Compliant politicians can be rewarded with not only contract awards and policy changes but also future lucrative jobs with international companies receiving economic benefits from a government (Economist, 2017e). In addition, it is well-recognized that state-owned firms can provide government-sponsored benefits to agents with powerful political influence (Economist, 2017i). Expenditures by foreign firms to serve the interests of politicians can also be used to buy influence (Economist, 2017ad). Political spending doesn't always pay off quickly and is recognized to often require persistence that can take many different forms, including via subsidizing government investments, arranging beauty contests, and developing political connections across borders, as indicated by Roth (2017), who explained examples of the intricate web of cross-lobbying over many years between Trump and various Russian agents and politicians. Even foreign aid from wealthy to less rich countries is subject to the influence of political lobbying by private firms attempting to win contracts to supply the aid, despite a history of inefficiency and corruption by such companies in fulfilling awarded contracts (Economist, 2017a).
} 


\section{Articles}

benefits to the politicians in power and their business supporters that give China bases in the Indian Ocean if the loans aren't repaid (Economist, 2018i). China has also attempted to influence public opinion and governments of countries across the world through direct pressure that has successfully had negative information about China censored even in major worldwide data bases used for academic research, pushed non-profit institutions and Chinese students studying in foreign countries to promote a more positive view of Chinese government positions, and meddled directly in foreign politics through campaign contributions by its businesses (Economist, 2017aj).

Somewhat more subtly, the International Monetary Fund (IMF), which is controlled as well as largely funded by the wealthier countries in the world like Europe, Japan, and the U.S., provides relatively inexpensive loans to economically less developed countries (LDCs) needing financing. In return, government recipients of its financing are typically required to adopt free market policies which essentially give large international
An Analysis of the Use of Money to Divert the Exercise of Government Power for the Wealthiest

corporations free reign to maximize profits in those countries. However, because such demanded economic policies have often in the past had rather draconian impacts on the LDC populations, the IMF is beginning to require less stringent conditions for its loans that allow more social spending for the recipient countries' people than was allowed historically (Economist, 2017fg). The latter changes in IMF terms (such as less mandatory cuts in government spending for education, infrastructure, and health care) reduce the political risks associated with the historically harsher measures dictated by the IMF. ${ }^{15}$ In particular, less stringent IMF policies decrease the risk of default on loans from the IMF and wealthy lenders because of the resulting lower chance of political upheavals in the LDCs that might otherwise occur and that could cause the LDCs to refuse to make payments on their debts to the richer countries of the world (and may also be accompanied by a reversal in the nations' pro-business reforms that can impinge on the profits of international corporations). ${ }^{16}$

\footnotetext{
${ }^{15}$ This change in the IMF's perception of the long-term benefits of some social spending is occurring at the same time as people in many LDCs have come to more positively view the long-term economic benefits of free markets in many LDCs. For instance, Southeast Asia has generally moved toward more free markets (in some cases promoted by communist and dictatorial governments) due to past experiences with controlled markets (Economist, 2017p). These two developments are not conflicting ones, as free markets can exist alongside substantial government expenditures for some social purposes such as education and health care, as Singapore indicates can be economically successful (Economist, 2017c). At the same time, recent empirical evidence indicating that "democracy" is a positive economic factor, at least with respect to more democratic countries better able to repay their debts (Dellis, Hasan, and Ongena, 2017), implies that a combination of government social spending, free markets, and democracy is a winning combination long-term. However, the specified definition of "democracy" used in the latter research doesn't reflect the persuasive power of money to influence voting outcomes and so may simply be reflective of voters in countries defined as "democracies" acquiescing more cooperatively in serving the interests of the wealthy.

${ }^{16}$ Across countries worldwide, there is always the risk of politicians seizing power by means other than elections, as in a coup, insurrection, or invasion by a foreign power. Because the risk of violent group actions are increased when people collectively feel powerless with little or no hope of an improvement in their situation as well as contemptuous of an oppressive system which they perceive to treat them unfairly (Tausch, Spears, Saab, Becker, Christ, and Singh, 2011), all government leaders are motivated to undertake policies for the people they rule with more opportunities to advance and better service to their needs in order to reduce the probability of being overthrown. However, there tends to be limits on how far such service to the local people can go if it disturbs the "interests" of the richer countries and their international corporations. For instance, elections, governments, and state policies can be strongly influenced by U.S. sponsored/financed subversion, economic warfare like embargoes, coups, and invasions (and threats thereof), as well as by U.S. funding of compliant politicians (Murphy, 2000). Nevertheless, despite the feeling of powerlessness thereby created worldwide, many still struggle and vote for government policies favoring their own people as opposed to U.S. corporate interests, including successfully in Venezuela over decades of overwhelming American pressure that continues (Steffin, 2017). Although Venezuela has been racked by strong internal resistance from local business
} 


\section{Appendix II}

\section{Discussion of the Possibility of a More Democratic System of Rule by and for the People}

This paper demonstrates the strong power of money to influence government policy across the world. It is useful here to discuss the likelihood of an election of a government that can be empowered to change the capitalist system of political economy to better maximize the utility of all individuals as opposed to big-moneyed interests. ${ }^{17}$

In particular, a greater awareness among people that their votes serve to have them acquiesce in government by and for the wealthy can create natural human resentment to drive down the bn: 1 for any politician $n$ serving the wealthy Agent \#1 and thus make it more costly for the rich to buy government power according to (2). Such resentment could potentially make it prohibitively expensive for big money interests to be able to continue to profitably control government actions according to (1). The large amount of support and votes in the U.S. 2016 Democratic Party primaries for the self-proclaimed socialist Bernie Sanders, who refused any corporate campaign contributions, provide evidence of the potential for such a disenchantment with politicians perceived to be controlled by large corporate donors.

However, any attempt to cause voters to elect politicians advocating any sort of such revolutionary changes would face incredible hurdles because of a long history of big-money interests promoting the risks and potential disasters associated with radical political ideas being adopted. For instance, egalitarian politicians are often discredited by misleadingly comparing them to leaders of past unsuccessful applications of communism, and ecological parties like the Greens are frequently portrayed as "tree-hugging" fanatics that seek to return humans completely to primitive nature. The problems associated with voters choosing the lesser of two pro-business "evils" within the existing political system in the U.S. that have established brand names, which were bought by billions of dollars in past political expenditures, ${ }^{18}$ would have to be overcome

interests and the more affluent citizens of that nation, which has led to, black markets, corruption, high inflation, shortages in even food and medicine, a 35\% decline in real GDP since 2013, an unpopular attempt by the reigning socialist President to enact more autocratic rule, and financial default on its foreign debt, the Chavista brand of populist socialism begun several decades ago in Venezuela is still backed by a majority of the people in that country (Economist, 2017s).

${ }^{17}$ Such a changed system of rule could potentially take many forms. For instance, government actions could be decided by online voting by the masses of people. However, government by plebiscite alone would not prevent big money from controlling government policy. In particular, unless there were some way to create an egalitarian system that facilitates equal capability for individuals to promote their opinions about different government actions (such as might be feasible through a free internet and a democratic means of using the public airwaves for communication purposes), agents with more resources would still be able to spend more to influence votes on issues relevant to them and thus buy government power. In addition, even with a system that somehow creates a more democratic media and voting, large corporations and the wealthy, who own and control most businesses, could still utilize the power of their capital to bribe or threaten others with respect to their commercial investments that provide jobs, higher wages, etc. Thus, in order for government to serve all people equally (as opposed to those with more resources), it might be necessary for all agents to have equal capacity to expend political capital in some sort of system where those with more money would not be able to affect or control investments, jobs, wages, etc. Only such a system might result in government serving the interests of all individuals in an egalitarian fashion whereby government satisfies some equally weighted utility function of all human beings.

${ }^{18}$ Besides direct campaign contributions to the two mainstream pro-business parties in the U.S., billions of dollars in political expenditures of all types have long been made to vilify government as being run by corrupt leaders, who serve only their own personal interests, whereas businesses are promoted as benevolent efficient producers of goods and services for the good of customers and the employees they pay. Pro-business third parties like the U.S. Libertarians benefit from such general probusiness propaganda and thus tend to receive far more votes than the U.S. Greens. Nonetheless, the relative weakness of 


\section{Articles}

for any radical changes whatsoever to the existing political and economic order. The low 5\% percentage vote totals for "third party" Presidential candidates in the U.S. in 2016 despite over $\$ 10$ million in campaign spending by those dark horses would seem to make these difficulties virtually insurmountable. ${ }^{19}$

Any unestablished politicians or parties like the Greens, which have never won any elections at the national level in the U.S. (and are thus perceived to have little or no chance of winning based on past history) would likely need to have at least enough political expenditures to increase the votes for their candidates to over $30 \%$ of the national electorate in order to avoid the motivation voters have to instead engage in strategic voting (see footnote \#7). Prior political research has found a cost to buy a vote in the U.S. to be $\$ 145$ (Bombardini and Trebbi, 2011), thus implying obtaining $30 \%$ of the 136 million votes in the U.S. in 2016 would cost
An Analysis of the Use of Money to Divert the Exercise of Government Power for the Wealthiest

$\$ 145 \times 0.30 \times 136$ million $=\$ 5.916$ billion, which might be the minimum political expenditure for a third party to have a reasonable chance of winning the U.S. Presidency. ${ }^{20}$

Even if an extremely large amount of political expenditures were somehow made to promote radical changes in the economic and political system, that money would still have to compete with the large sums already given by corporations and the affluent in order to buy government leaders and policy within the existing system. Billions of more dollars could optimally and feasibly be spent each year by the wealthy to protect their interests and power if there was some non-trivial risk that government leaders could be elected who might change the system that is beneficial to those with greater wealth. ${ }^{21}$ In particular, defining the U.S. Republican and Democratic Parties representing rich agents $j=1$ as $\mathrm{n}=1$ and $\mathrm{n}=2$, while designating agents and politicians seeking radical changes as $j>2$

such third-party brand names, combined with strategic voting, results in the well-established pro-business parties winning far more votes than any third party.

${ }^{19}$ The electoral triumphs of the Republican billionaire Trump for the benefit of the wealthiest individuals and the businesses they own, combined with the vote totals of only $1.1 \%$ for the Green Party in 2016 (that would appear to have far better represented the interests of most Americans), are indicative of how large amounts of money can persuade voters to acquiesce in continued rule by the wealthy elites. In particular, Trump marketed himself to be appealing to many voters because he ran on a campaign of being independent of big-money interests, even though he himself was a billionaire, freely accepted large corporate donations, and ran on a campaign program that was much more pro-rich and pro-corporate than even the other mainstream pro-business party's candidate Clinton did.

${ }^{20}$ Such amounts to promote a non-mainstream politician without an established party brand name might be made with relatively small donations of money and volunteer campaigning from individuals. For instance, if there were as many as 10 million people who collaborated in the effort, the average contribution could be as little as $\$ 600$ each. Since many individuals might find such a monetary contribution to be more than they can afford or want to risk, they might be more likely to make contributions in the form of volunteer labor associated with direct persuasion of eligible voters, as well as simultaneously recruiting other supporters who might increase the political expenditures of time and money. If such contributed work were worth at least the minimum wage of $\$ 10$ per hour, the necessary total effort needed might involve 10 million supporters working an average of 6 hours per week for 10 weeks.

${ }^{21}$ Green and Krasno (1988) long ago showed that political expenditures do increase when challengers pose more of a threat. However, it should be mentioned that those authors found that there is a decreasing return to spending (in terms of acquiring votes) as the expenditures rise. Thus, an alternative to the two corporate-sponsored party candidates might have a chance in the U.S. if enough resources could be garnered to reach a critical mass of support that would make the likelihood of victory sufficiently high to offset the benefits voters expect to receive from selecting from the lesser of the alternative two "evils". Once sufficient backing has been won, the movement could gather momentum that might in turn attract more funding in a circularly reinforcing manner. Sanders' near success in winning the Democratic Party primary election represents a recent example of such a process. However, a candidate running on a third party ticket (including Sanders himself if he had chosen to do so after losing the Democratic primary) must still overcome the hurdle associated with all the prior money spent in prior elections by the two main U.S. parties that has created brand names that makes them appear unbeatable and thereby drives down the utility voters expect to derive from casting ballots for third party politicians. 


\section{Articles}

and $n>2$, respectively, a larger $c_{j: n}$ for $j>2$ in (1) might only cause $c_{1: 1}$ and $c_{1: 2}$ to rise much more. The fact that corporations earn returns on political expenditures that may exceed $2500 \%$ (Jayachandran, 2006) implies that far larger political expenditures by the wealthy are possible without violating the constraint in (1).

The fact that in 2017 the Republicans raised a record amount of money that was over twice as much money as the Democrats (Allison and. McCormick, 2018), despite extraordinarily high disenchantment among voters about the recent Republican-controlled government actions more beneficial to the wealthy, represents an indication of wealthy agents increasing their bids when $\mathrm{b}_{1: 1}^{*}$ is very low. Moreover, a 2018 poll indicating that Joe Biden is preferred to Sanders for President in 2020 (Easley, 2018), despite this prior Vice President of the U.S. being a centrist favoring policies more friendly to business and the wealthy than Sanders, implies a very low chance of a radical change in U.S. government policy. Thus, radical changes appear rather remote in the U.S., whose government by and for wealthy agents can, and is motivated to, utilize its enormous military, economic, and political power to inhibit any radical changes in other countries that adversely impact the interests of those with money (Murphy, 2000). The continued dollarization of the world economy itself creates dependence on U.S. policies (Economist, 2018y).

Moreover, the existence of multiple candidates with little chance of being elected can split the resources and votes of those protesting government insiders and politicians perceived to be corrupt and/or controlled by big-money interests. Any individually preferred candidate promising to represent such voters opposed to the ruling parties staying in power therefore has even less chance of winning a plurality of the popular vote. The propensity to vote for a lesser "evil" is increased to the extent that an eligible voter chooses to bother to vote at all due to a perceived futility of it all (Murphy, 2019b). Sometimes ruling parties even support additional "protest" candidates for that purpose, as they recognize that splitting the votes against the system among more than one anti-establishment politician reduces the chances of any such candidates actually winning even a meaningful number of votes (Economist, 2017af).

\section{References}

J. Addoum, S. Delikouras, D. Ke, and A. Kumar "Underreaction to Political Information and Price Momentum." Financial Management (2018).

B. Allison and J. McCormick. "Democrats Gain Momentum in Money Race Fueling Midterm Contests." Bloomberg.com (February 1, 2018), https://www.bloomberg. com/news/articles/2018-02-01/democratsgain-momentum-in-money-race-fuelingmidterm-contests

S. Ansolabehere, J. Figueiredo, and J. Snyder. "Why is there so Little Money in U.S. Politics." Journal of Economic Perspectives 17 (2003), 105-130.

J. Ateljevic and J. Budak. "Corruption and Public Procurement: Example from Croatia." Journal of Balkan and Near Eastern Studies 12 (2010), 375-397.

A. Balcerzak. "Where the Money Came From, Not How Much, Mattered in the 2016 Presidential Race." OpenSecrets.org (November 9, 2016). https://www.opensecrets. org/news/2016/11/where-the-money-camefrom-not-how-much-mattered-in-thepresidential-race/

T. Bassetti and F. Pavesi. "Electoral Contributions and the Cost of Unpopularity." Economic Inquiry 55 (2017), 1755-1791. 


\section{Articles}

M. Beckel. "Top U.S. Corporations Funneled $\$ 173$ Million to Political Non-Profits." The Center for Public Integrity (January 16, 2017), https://www.publicintegrity. org/2014/01/16/14107/top-us-corporationsfunneled-173-million-political-nonprofits

V. Boehm. Macroeconomic Theory. Springer Publishing: New York (2017).

M. Bombardini and F. Trebbi. "Votes or Money? Evidence from the U.S. Congress." Journal of Public Economics 65(2011), 587611.

A. Bradford and J. Kagel. "Legislative Bargaining with Teams." Games and Economic Behavior 93 (2015), 117-127.

D. Broadwin. "The Chamber's Secrets." U.S.News (October 25, 2015), https://www. us news.com/opinion/economicintelligence/2015/10/22/who-does-the-uschamber-of-commerce-really-represent

J. Catalinotto. "Two Faces of World Imperialism." Workers World (November 15, 2018), 5.

M. Cooper, H. Gulen, and A. Ovtchinnovkov. "Corporate Political Contributions and Stock Returns." Journal of Finance 65 (2010), 687724.

S. Das. "Extend-and-Pretend Model Can't Work Forever." Bloomberg (February 4, 2018), https://www.bloomberg.com/view/ articles/2018-02-04/extend-and-pretendcan-t-work-forever

M. Dellis. "The Two-Party System under Alternative Voting Procedures." Social Choice and Welfare 40 (2013), 263-284.

M. Dellis, I. Hasan, and S. Ongena. "Democracy and Credit." 10th Swiss Conference of Financial Intermediation (2017).

M. Dunkel. "French Election: Class Struggle Confronts Reaction." Workers World (April 10, 2017), 10.
An Analysis of the Use of Money to Divert the Exercise of Government Power for the Wealthiest

C. Dowling and A. Wichowsky. "Does It Matter Who's Behind the Curtain? Anonymity in Political Advertising and the Effects of Campaign Finance Disclosure." American Politics Research 41 (2013), 965996.

A. Dyck, D. Moss, and L. Zingales. "Media Versus Special Interests." Journal of Law \& Economics 56 (2013), 521-553

J. Easley. "Poll: Biden Holds Double-Digit Lead Over Field of 2020 Dem Presidential Contenders." The Hill (January 18, 2018), h t t p : / / he hill . com / homenews / campaign/369555-poll-biden-holds-doubledigit-lead-over-field-of-2020-dem-presidential Economist. "Doing Good, Doing Well." May 6 (2017a), 55-56.

Economist. "Doorway to Profit." May 20 (2017b), 56.

Economist, "The Blind Man's Elephant." June 3 (2017c), 36.

Economist. "How to Be Wrong." June 10 (2017d), 75.

Economist. "Meddle Kingdom." June 17 (2017e), 36-37.

Economist. "The Business of Tax." June 17 (2017f), 56.

Economist. "Return of the Loan Arranger." June 17 (2017g), 67.

Economist. "Wages through the Ages." June 17 (2017h), 67.

Economist. "National Treasure." June 17 (2017i), 70.

Economist. "Herd it All Before." June 24 (2017j, 36.

Economist. "The Power of Groupthink." July 1 (2017k), 3-10.

Economist. "Wantonk and No Action." July 1 (2017I), 32-33.

Economist. "Doctor on Call." July 1 (2017m), 36. 
Economist. "Wrong and Stable." July 1 (2017n), 65.

Economist. "Machine Learning." July 22 (20170), 15-18.

Economist. "More Money, Less Freedom." July 22 (2017p), 29-30.

Economist. "Degrees of Disenchantment." July 22 (2017q), 31.

Economist. "A Thousand Golden Stars." July 22 (2017r), 35-36.

Economist. "The Mess Tropical Marxism Makes." July 29 (2017s), 19-22.

Economist. "For Whom Bell Pottinger Tolls." July 29 (2017t), 39-40.

Economist. "Chaining Giants." August 12 (2017u), 46-47.

Economist. "Don't Celebrate Yet." August 19 (2017v), 42.

Economist. "Washington Wizards."

September 2 (2017w), 20.

Economist. "Mr. Trump's History Lessons."

September 2 (2017x), 28.

Economist. "If You Elect a Clown, Expect a Circus." September 2 (2017y), 29.

Economist. "One-Click Shopping." September 16 (2017z).

Economist. "Left Behind." September 16 (2017aa), 23-24.

Economist. "The Point of Patouflage." September 16 (2017ab), 64.

Economist. "Regeneration." September 30 (2017ac), 3-12.

Economist. "Trudeau's Flying Unicorn Hits a Storm." October 14 (2017ad), 29-30.

Economist. "Elections on a Shoestring." October 14 (2017ae), 30.

Economist. "Center Ring." October 28 (2017af), 48.

Economist. "Donate or Else." November 18 (2017ag), 57.
Economist. "America Inc Gets Woke." December 2 (2017ah), 53-55.

Economist. "How to Get it Back." December 2 (2017ai), 75.

Economist. "At the Sharp End." December 18 (2017aj), 20-22.

Economist. "The Presidential Hostage." January 6 (2018a), 20-21.

Economist. "The Year of the Incumbent." January 6 (2018b), 49.

Economist. "Salting the Earth." January 27 (2018c), 28.

Economist. "Fear of Failing." January 27 (2018d), 31.

Economist. "A Dangerous Waltz." February 3 (2018e), 17-19.

Economist. "Go Beset a Watchman." February 3 (2018f), 35.

Economist. "Dancing the Cha-Cha." February 3 (2018g), 36.

Economist. "The Ills of Latin American Democracy." February 10 (2018h), 32.

Economist. "A Tropical Tempest." February 10 (2018i), 37.

Economist. "Get Out of Jail Free." February 10 (2018j), 57-58.

Economist. "Changing the Pilots." February 10 (2018k), 58.

Economist. "Stop Theft." March 10 (2018I), 16-17.

Economist. "The Battle for the Conurbano." March 24 (2018m), 32.

Economist. "Hun Senescence." March 24 (2018n), 38.

Economist. "The Perky Portuguese." March 31 (20180), 47.

Economist. "Birds of a Feather." March 31 (2018p), 55.

Economist. "Getting a Handle on a Scandal." March 31 (2018q), 68. 


\section{Articles}

Economist. "The Humbling of the Tycoons." April 21 (2018r), 12.

Economist. "An Eruption in Nicaragua." April 28 (2018s), 10.

Economist. "The Big Beige Book." April 28 (2018t), 42.

Economist. "Into the Sands." April 28 (2018u), 59-60.

Economist. "Vacuum Power." May 19 (2018v), 31-32.

Economist. "The Worth of Nations." May 5 (2018w), 72-73.

Economist. "Second Time, Farce." May 5 (2018x), 79k .

Economist. "What the OFAC." May 19 (2018y), 54-55.

Economist. "Workers of the Galaxy, Don't Unite." May 19 (2018z), 56.57.

Economist. "Bought and Paid for." October 6 (2018aa), 70.

Economist. "Soft Power and Censurship." October 20 (2018ab), 45-46.

P. Fishburn. Utility Theory for Decision Making. Krieger: Malabar (1979).

D. Fischer. "'Dark Money' Funds Climate Change Denial Efforts." Scientific American (December 23, 2013), https://www. scientificamerican.com/article/dark-moneyfunds-climate-change-denial-effort/

N. Fleming. "Eating our Way to Hell." NewScientist (November 20, 2018), 44.

F. Goldstein. "Front Man for Wall St., Pentagon." Workers World (June 1, 2017), 3.

D. Green and J. Krasno. "Salvation for the Incumbents: Re-estimating the Effects of Campaign Spending in House Elections." American Journal of Political Science 32 (1988), 884-907.

D. Green, M. McGrath, and P. Aronow. "Field Experiments and the Study of Voter
An Analysis of the Use of Money to Divert the Exercise of Government Power for the Wealthiest

Turnout." Journal of Elections, Public Opinion and Parties 23 (2013), 27-48.

G. Grossman and E. Helpman. "Electoral Competition and Special Interest Politics." Review of Economic Studies 63 (1996), 265-286.

G. Grossman and E. Helpman. Special Interest Politics. MIT Press: Cambridge (2001).

D. Hasemyer. "In Setback for ExxonMobil, Texas Judge Kicks Climate Change Case to New York." Inside Climate News (March 30, 2017), https://insideclimatenews.org/ news/30032017/exxonmobil-climate-changeresearch-ny-attorney-general-investigation

R. Hasen, "Lobbying, Rent Seeking, and the Constitution." Stanford Law Review (2012), 191-254.

E. Herman and N. Chomsky. Manufacturing Consent: The Political Economy of the Mass Media. Pantheon Books: New York (1998).

M. Hill, W. Kelly, B. Lockhart, and R. Van Ness. "Determinants and Effects of Corporate Lobbying." Financial Management 42 (2013) 931-957.

L. Holmes. "'Marx's View of the Working Class includes all Struggles." Workers World (June 7, 2018), 7.

Gregory Huber and Kevin Arceneuaux. "Identifying the Persuasive Effects of Presidential Advertising." American Journal of Political Science 51 (2007), 957-977.

M. Kaske. "The Woman Fixing Puerto Rico's Finances Knows not to Waste a Crisis." Bloomberg (March 31, 2019), https://www. garp.org/\#!/risk-intelligence/all/ all/a1Z1W000004vzGoUAl? utm content=April____2019\&utm _ source $=a f f i l i a t e s \& u t m$ $\mathrm{m}$ e d i u $\mathrm{m}=\mathrm{e} \mathrm{m}$ a i l \& u t m campaign=dailynews\&utm_term=article5

J. Keynes. The General Theory of Employment, Interest and Money. Macmillan: London (1936). 


\section{Articles}

M. Klar and T. Kasser. "Some Benefits of Being an Activist: Measuing Activism and its Role in Psychological Well-Being." Political Psychology 10 (2009), 755-777.

S. Jayachandran. "The Jeffords Effect." Journal of Law and Economics 49 (2006), 397-425.

K. Marx. Kommunitische Manifesto. Bildungs-Gesellschaft fuer Arbeiter: London (1848).

K Marx (edited by F. Engels). Das Kapital: Buch I (1867), Buch II (1885), Buch III (1894), Otto Meisner Verlag: Hamburg (reprinted by Deitz Verlag, Berlin, in 1988).

S. Meunier. "The French Presidency is a Bargain." TheWorldPost (2017), https:// www.huffingtonpost.com/sophie-meunier/ france-election-laws_b_1438456.html

S. Millies. "Three Pigs that Snatched $\$ 803$ Million." Workers World (March 12, 2015), 10-11.

A. Murphy. The Triumph of Evil: The Reality of the U.S. Cold War Victory. European Press Academic Publishing: Florence (2000).

A. Murphy. The Meaning of Life, the Universe, and Nothing. European Press Academic Publishing: Florence (2011).

A. Murphy. "A Model of Optimizing Political Expenditures to Buy Government Power." Economics and Politics (2019a).

A. Murphy. "A Simple Model Explaining the Interaction of Between Special Interest Spending and Voter Choices." Jounral of Economics and Political Economy (2019b).

J. Muth. "Rational Expectations and the Theory of Price Movements." Econometrica 29 (1961), 315-335.

J. Nash. "The Bargaining Problem." Econometrica 18 (1950a), 155-162.

J. Nash. "Equilibrium Points in n-Person Games." Proceedings National Academy of Sciences 36 (1950b), 48-49.
E. Negin. "Exxon-Mobil is Continuing to Fund Climate Science Deniers." Huffpost (July 14, 2016), http://www.huffingtonpost. com/elliott-negin/exxonmobil-is-stillfundi_b_10955254.html

F. Passarelli and G. Tabellini. "Emotions and Political Unrest." Journal of Political Economy 125 (2017), 903-946.

R. Peeters, R. Saran, and A. Yueksel. "Strategic Party Formation on a Circle and Durverger's Law." Social Choice and Welfare 47 (2016), 729-759.

M. Raposo. "Brazilian Elections: a Political Discussion." Workers World (2019), 11.

T. Rees. "The Human and the Machine: What Most Commentators Get Wrong About A.I." HuffPost (December 5, 2016), https:// www.huffingtonpost.com/entry/the-humanand-the-machine-what-most-commentatorsget_us_5845676ee4b0b93e10f8e412

B. Ritholz. "Stakeholder Capitalism will Fail if it's just Talk." Bloomberg (August 21, 2019), $\quad$ https://www.garp.org/\#!/riskintelligence/all/all/a1Z1W000003m8vnUAA?utm_ content=August_22_2019\&utm_ source=audience\&utm_medium=email\&utm_ campaign=dailynews\&utm_term $=$ article 6

M. Robinson. "Deutsche Bank to pay $\$ 16.2$ Million in 'Princeling' Bribery Case." Bloomberg (August 23, 2019), https://www. garp.org/\#!/risk-intelligence/all/all/ a 1Z1W000003 m 9AQUAY? ut m _ content=August_23_2019\&utm_ source=audience\&utm_medium=email\&utm_ campaign=dailynews\&utm_term=article 6

A. Roth. "The Man Who Drives Russia's Trump Connection." Washington Post (July 22, 2017), https://www.washingtonpost. com/ world/e u rope/th e - manw h o-drives-trumps-rus s i a connection/2017/07/21/43485a0e-6c9811e7-abbc-a53480672286_story.html?utm term $=.4 \mathrm{f} 683285328 \mathrm{e}$ 


\section{Articles}

M. Schere, D. Waigel, and K. Tumulty. "Democrats Express Outrage over Early Party Control for Clinton in 2016." Washington Post (November 2, 2017), https://www.washingtonpost.com/politics/ democrats-express-outrage-overallegations-of-early-control-for-clinton-in2016/2017/11/02/84e949da-c000-11e7-97d9bdab5a0ab381_story.html?utm_term=. a6cff51ad658

T. Schmidt. "Renters Resist Landlord Lies." Workers World (June 22, 2017), 2.

R. Shapiro. "The Politics of Widening Inequality in the United States, 1977-2014." SSRN paper 3084843 (2017).

G. Schweizer. "Bill Clinton's Pardon of Marc Rich Continues to Pay Big." New York Post (January 17, 2016), https://nypost. com/2016/01/17/after-pardoning-criminalmarc-rich-clintons-made-millions-off-friends/

J. Steffin. "The Gains of the Bolivarian Revolution." Workers World (July 27, 2017), 9.

G. Stigler. "The Theory of Economic Regulation." Bell Journal of Economics and Management Science 2 (1971), 3-21.

N. Tausch, R. Spears, R. Saab, J. Becker, O. Christ, and P. Singh.
An Analysis of the Use of Money to Divert the Exercise of Government Power for the Wealthiest

Explaining Radical Group Behavior: Developing Emotion and Efficacy Routes to Normative and Nonnormative Collective Action." Journal of Personality and Social Psychology 101 (2011), 129-148.

J. Von Neumann and O. Morgenstern. Theory of Games and Economic Behavior. Princeton University Press: Princeton (1953).

H. Wang and C. Qian. "Corporate philanthropy and Firm Financial Performance: The Roles of Shareholder Response and Political Access." Academy of Management 54 (2012), 1159-1181.

B. Watson. "Pro-Sustainability Companies Funding Climate Change Denial." Guardian (September 25, 2014).

M. Zahn. "Exclusive: 'Ready to Stomp on it": Documents Reveal Staggering Power of Tech Giant Lobbying." Yahoo Finance (August 22, 2019), https://finance.yahoo.com/ news/facebook-google-amazon-apple-statelobbying-170525755.html

A. Zardroohi. "Market Structure and Campaign Contributions: Does Concentration Matter? A Reply." Public Choice 36 (1988), 187-191. 